Journal of Applied Biology \& Biotechnology Vol. 5 (02), pp. 068-071, March-April, 2017

Available online at http://www.jabonline.in

DOI: $10.7324 / \mathrm{JABB} .2017 .50210$

(c) $\mathrm{BY}-\mathrm{NC}-\mathrm{SA}$

\title{
In vitro antagonistic activity of a root endophytic fungus towards plant pathogenic fungi
}

\author{
K. Talapatra ${ }^{1}$, A. Roy $\operatorname{Das}^{2}$, A. K. Saha ${ }^{2}$, P. $\operatorname{Das}^{1} *$ \\ ${ }^{1}$ Microbiology Laboratory, Department of Botany, Tripura University Suryamaninagar-799 022, Tripura, India. \\ ${ }^{2}$ Mycology and Plant Pathology Laboratory, Department of Botany, Tripura University Suryamaninagar-799 022, Tripura, India.
}

\section{ARTICLE INFO}

Article history:

Received on: 27/09/2016

Accepted on: 29/12/2016

Available online: 20/03/2017

\section{Key words:}

Antagonistic activity,

Trichoderma viride, endophytic

fungi, plant pathogenic fungi.

\begin{abstract}
The biocontrol measures against pathogens are widely recognized as a step towards organic agriculture. In the present study, nine species of endophytic fungi and four plant pathogenic fungi were tested against antagonistic activity of a root endophyte, Trichoderma viride. Out of nine endophytic fungi, eight were inhibited. The inhibitory effect was maximum against Alternaria sp. and Pythium sp. The minimum zone was noticed against Nigrospora sp. after 14 days of incubation. It showed no inhibitory effect against an isolate of Aspergillus sp. and overgrew it after 9 days of incubation. T. viride showed antagonistic activity against all the four plant pathogenic fungi. The antagonistic zone was highest against Colletotrichum capsici and lowest was observed in Alternaria solani after 14 days of incubation. The study suggests the potential of an endophytic strain of fungus and it may be used in biocontrol programmes of plant diseases in the region.
\end{abstract}

\section{INTRODUCTION}

The use of chemicals for the control of the disease is not economically feasible. With repeated use of these chemicals leave harmful residues and can lead to the development of resistance in pathogens [1]. Hence, interest has been developed for safer non chemical methods to control disease that is effective and causes less risk to human health and environment [2]. Fungicides replacement with bio-control agents is an alternative means to control the plant pathogens, produce safety food and reduce the environment pollution [3]. Trichoderma species are one of the most important bio-control agents and most frequently isolated from soil and root zone of plants [4]. Trichoderma strains are antagonistic to some plant pathogenic fungi because they have the ability to suppress the diseases [5]. Trichoderma uses several mechanisms such as antibiosis, myco-parasitism and competition for nutrients and space, and is also able to promote growth and development of plant and induce the defense response of plants [6]. Several Trichoderma species have been extensively studied for their potential to control diseases in several crops [4]. Recently, several species of endophytic fungi belonging to

\footnotetext{
* Corresponding Author

E-mail: pannal1d@gmail.com

Tel.:+913812379435; fax: +913812374802
}

Trichoderma species has been isolated [7]. Antagonistic activity of endophytic fungi, Trichoderma viride was tested towards Diplodia corticola [8]. Therefore, the aim of our study is to determine in vitro inhibitory effect of the root endophytic fungi, Trichoderma viride against some endophytic fungal species isolated from invasive plants and also to test antagonistic activity against some plant pathogenic fungi.

\section{MATERIALS AND METHODS}

\subsection{Isolation of endophytic fungi}

Aspergillus sp., Cladosporium sp., Curvularia sp., Fusarium sp., Penicillium sp., and Trichocladium sp. were isolated from the roots of Tridax procumbens, Ageratum conyzoides, Blumea laciniata, Crassocephalum crepidioides, Eclipta prostrate and Synedrella nodiflora, respectively. Nigrospora sp. and Pythium sp. were isolated from the roots of Vernonia cinerea. T. viride and Alternaria sp., were recovered from the roots of Spilanthes paniculata from Suryamaninagar, Tripura in Northeast India. Roots were cut into several small segments $(0.5 \mathrm{~cm})$ and surface-sterilization was done by immersing sequentially in $70 \%$ ethanol for $2 \mathrm{~min}, 0.5 \%$ sodium hypochlorite $(\mathrm{NaOCl})$ for $3 \mathrm{~min}$ and then rinsing thoroughly with sterile distilled water. The surface-sterilized roots were then air-dried under laminar air flow chamber. 
Using a sterile needle, the tissues were gently teased and the root $(0.5 \mathrm{~cm}$ in length) were cut with sterile blade and plated on Malt Extract Agar (MEA) media amended with streptomycin $(100 \mu \mathrm{g} / \mathrm{ml})$. The plates were sealed with parafilm and incubated in a BOD incubator at $25^{\circ} \mathrm{C} \pm 2$ for one to three weeks. The hyphae growing out from the plated segments were immediately transferred into MEA, purified and maintained. The fungal isolates were identified on the basis of culture characteristics and morphology of conidia, and hyphal pattern by using available standard descriptions, photographs and illustrations $[9,10,11]$.

\subsection{Plant pathogenic fungi}

For the analysis of the antagonistic activity of $T$. viride against plant pathogenic fungi four pathogenic fungi were brought from IMTECH, Chandigarh, India namely Alternaria solani (MTCC-2101), Colletotrichum capsici (MTCC-2071), Fusarium solani (MTCC-10130) and Pythium aphanidermatum (MTCC10247).

\subsection{Antagonistic activity by dual-culture method}

The antagonistic effect of the isolated strain of $T$. viride against different endophytic fungi viz., Alternaria sp., Aspergillus sp., Cladosporium sp., Curvularia sp., Fusarium sp., Nigrospora sp., Penicillium sp., Pythium sp. and Trichocladium sp. were evaluated using the dual-culture technique [12]. The same activity was examined against four pathogenic fungi. In this method, $2 \mathrm{~mm}$ size discs of culture of $T$. viride ( 5 days old culture) and the same size of another agar disc containing tested fungi were placed opposite to each other and close to the periphery of $90 \mathrm{~mm}$ petriplates containing MEA. For control, T. viride was placed in a similar manner on MEA petri plates. All pairing were carried out in three replicates and incubated at $25^{\circ} \mathrm{C} \pm 2$ for 14 days. The endophyte was considered to possess inhibitory effect if some endophytes and pathogens were not able to overgrow the hyphae of $T$. viride or if further growth of the pathogen ceased. After 7 and 14 days of incubation, the area between the two colonies at the interaction point was measured. After the desired incubation time, the growth of colonies of the tested fungi and antagonist was examined and photographed.

\section{RESULTS}

Nine different species of fungi namely Alternaria sp., Aspergillus sp., Cladosporium sp., Curvularia sp., Fusarium sp., Nigrospora sp., Penicillium sp., Pythium sp. and Trichocladium sp., isolated from different invasive plants were tested against the antagonist activity of an isolated root endophyte $T$. viride. The inhibitory activity of $T$. viride showed it effects against all the fungal species except Aspergillus sp. (Table 1).

In dual culture plates, zone was observed between the two colonies after 7 day and $14^{\text {th }}$ day of incubation, and the clear zone size varied among the antagonist and the fungi (Fig. 1). Although, the antagonists showed no inhibition zone with Aspergillius sp. and overgrew it by $100 \%$ after 9 days of incubation (Fig. 1 i). The inhibition zone was maximum against Alternaria sp. and Pythium sp. The minimum zone was noticed against Nigrospora sp. after 14 days of incubation (Table 1).
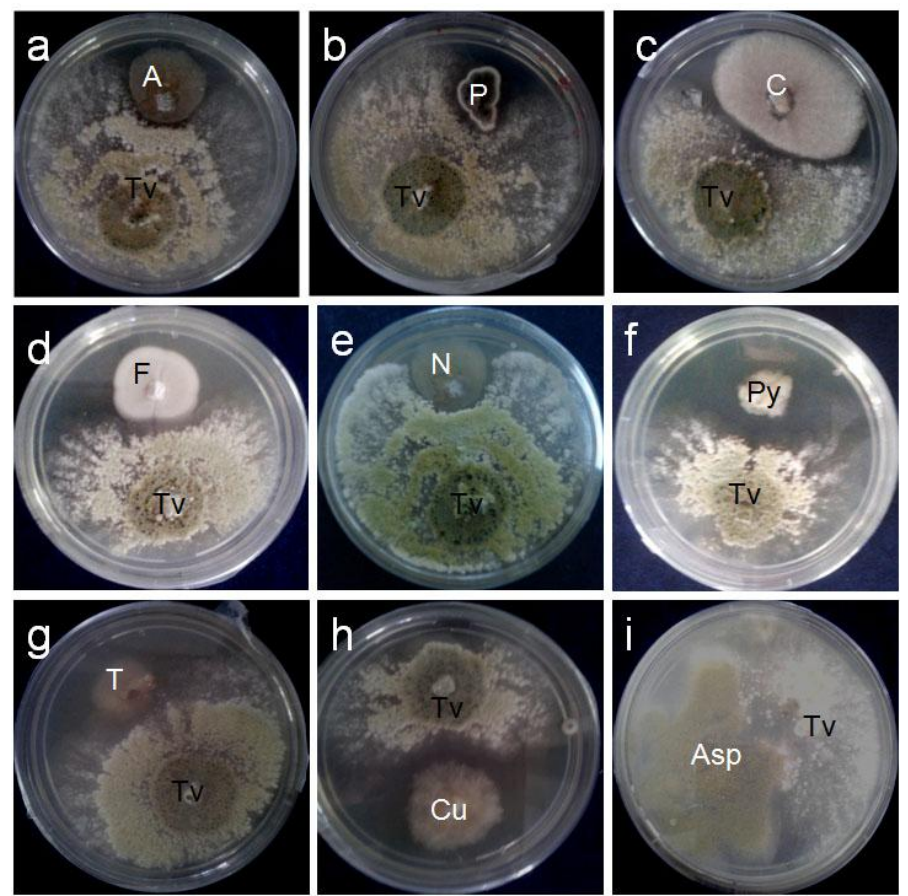

Fig. 1: Inhibitory effect of Trichoderma viride [Tv] against endophytic fungi. (a) Alternaria sp. [A] (b) Penicillium sp. [P] (c) Cladosporium sp. [C] (d) Fusarium sp. [F] (e) Nigrospora sp. [N] (f). Pythium sp. [Py] (g) Trichocladium sp. [T] (h) Curvularia sp. [Cu] and (i) Aspergillus sp. [Asp].

Table 1 Inhibition zone against different endophytic fungi by a root endophyte Trichoderma viride.

\begin{tabular}{lcc}
\hline Endophytic Fungi & After 7 days $(\mathbf{m m})$ & After 14 days $(\mathbf{m m})$ \\
\hline Alternaria sp. & $22.0 \pm 0.44$ & $8.3 \pm 0.08$ \\
Aspergillus sp. & $35.0 \pm 0.70$ & - \\
Cladosporium sp. & $29.0 \pm 0.80$ & $5.0 \pm 0.17$ \\
Curvularia sp. & $25.0 \pm 0.28$ & $6.3 \pm 0.33$ \\
Fusarium sp. & $22.0 \pm 0.39$ & $5.6 \pm 0.18$ \\
Nigrospora sp. & $17.0 \pm 0.39$ & $4.6 \pm 0.08$ \\
Penicillium sp. & $29.0 \pm 0.40$ & $5.7 \pm 0.22$ \\
Pythium sp. & $17.0 \pm 0.46$ & $8.3 \pm 0.06$ \\
Trichocladium sp. & $19.0 \pm 0.51$ & $7.3 \pm 0.12$ \\
\hline
\end{tabular}

Means of three replicates; \pm SE

T. viride showed antagonistic activity against all the plant pathogenic fungi (Fig. 2) Alternaria solani, Colletotrichum capsici, Fusarium solani and Pythium aphanidermatum. The inhibition zone between two colonies is presented in Table 2. The inhibition zone was highest against $C$. capsici and lowest zone was observed in A. solani after 14 days of incubation.

Table 2 Antagonistic zone against different plant pathogenic fungi by a root endophyte Trichoderma viride.

\begin{tabular}{lll}
\hline \multicolumn{1}{c}{ Pathogenic fungi } & After 7 days $(\mathbf{m m})$ & After 14 days $(\mathbf{m m})$ \\
\hline Alternaria solani & $17.0 \pm 0.08$ & $4.0 \pm 0.05$ \\
Fusarium solani & $20.0 \pm 0.05$ & $5.6 \pm 0.17$ \\
Pythium aphanidermatum & $19.3 \pm 0.20$ & $7.0 \pm 0.15$ \\
Colletotrichum capsici & $18.6 \pm 0.18$ & $7.3 \pm 0.12$ \\
\hline
\end{tabular}

Means of three replicates; \pm SE 

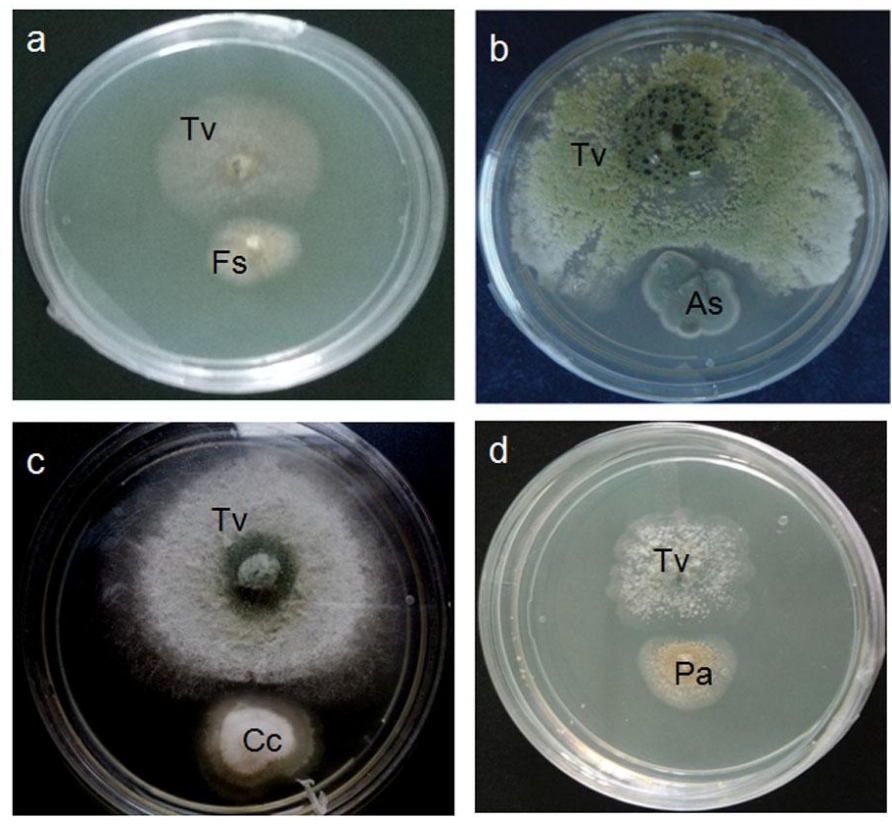

Fig. 2: Antagonistic effect of Trichoderma viride [Tv] against plant pathogenic fungi. (a) Fusarium solani [Fs] (b) Alternaria solani [As] (c) Colletotricum capsici $[\mathrm{Cc}]$ and (d) Pythium aphanidermatum $[\mathrm{Pa}]$.

\section{DISCUSSION}

Microorganisms are now used to control pathogens and pests to protect the important plants for human. Trichoderma spp. have been investigated as potential biocontrol agents because of their ability to reduce the incidence of disease caused by plant pathogenic fungi, particularly many common soil borne pathogens [13]. This is the first study of in vitro antagonism of an endophytic fungal strain, T. viride on endophytes and on pathogenic fungi viz., A. solani, C. capsici, F. solani and P. aphanidermatum. In the present study, the inhibitory effect of Trichoderma sp. on endophytes may be attributed to possibility of competition with other endophytes to colonize the root tissues of plants. Antagonistic activity of endophytic fungi, T. viride towards $D$. corticola was found to be maximum [8]. Naik et al. [14] reported antagonistic application of three endophytes from rice. Inhibitory effect of endophytes was studied on root rot pathogen, Heterobasidion parviporum [15]. In vitro and in vivo assays were carried out to test the efficacy of $T$. viride antagonist in controlling Fusarium circinatum causing pitch canker in Pinus [16].

The endophytic fungi $T$. viride showed antagonistic activity against all the fungi except Aspergillus but hyphae of $T$. viride overgrew on pathogen mycelium. The result may be attributed to the study of Mukherjee and Raghu [17] where it was found that no correlation exists between the ability of Trichoderma to produce antifungal antibiosis, and to control the disease. ElKatatny et al. [18] also found that T. harzianum exhibited no inhibition zone against Rhizopus sp. which is in accord with our study.

Fajola and Alasoadura [19] also observed antagonistic activity of $T$. harzianum on $P$. aphanidermatum which is in agreement with our study. C. capsici was also inhibited by
Trichoderma sp. as it was also reported earlier [20]. Ganie et al. [21] reported Trichoderma spp. have shown inhibition activity on A. solani which is in accord with our study. In the present study, Trichoderma sp. showed antagonistic effect against $F$. solani which is in agreement with the study of Naglot et al. [22] who showed that Trichoderma spp. inhibited $F$. solani. Trichoderma harzianum was found to suppressed wilt pathogen, Fusarium oxysporum as reported earlier [23].

Trichoderma strain shows antagonistic effect to some phytopathogenic fungi by the ability to suppress the diseases [5]. Trichoderma species also produces lytic enzymes which increase its antagonist action by acting in a synergistic way [24]. The antagonistic action of Trichoderma species against phytopathogenic fungi either by the secretion of cell wall hydrolytic enzymes or by the production of antibiotics [25]. These enzymes diffuses into cells and dissolves cell fragments of host cells and these cell fragments in turn induce the production of further enzymes and trigger a cascade of physiological changes, stimulating rapid and directed growth of Trichoderma species [26].

\section{CONCLUSION}

Examination of the antagonistic potential strain of root endophyte, T. viride is the initial step in utilizing the isolate for inhibitory application in laboratory conditions and it is found to be promising. This may find application in biocontrol programmes of plants used in agriculture and forestry in the region.

\section{ACKNOWLEDGEMENTS}

The authors are thankful to Head, Department of Botany, Tripura University for providing the laboratory facilities. KT is grateful to Department of Science and Technology, Govt. of India for the DST-INSPIRE fellowship. The authors are grateful to the anonymous reviewers for their suggestions to improve the manuscripts.

\section{Financial support and sponsorship: Nil.}

Conflict of Interests: There are no conflicts of interest.

\section{REFERENCES}

1. Vinale FK, Sivasithamparam EL, Ghisalberti R, Marra SL, Lento M. Trichoderma plant pathogens interactions. Soil Biology and Biochemistry. 2008; 40:1-10.

2. Cook RJ, Granados RR. Biological control: making it work. In: MacDonald MJF, editor. Agricultural biotechnology at the crossroads. Ithaca (NY). National Agricultural Biotechnology Council. 1991; 213-227.

3. Barakat RM, Al-Masri MI. Bilogical control of gray mold disease (Botrytis cinerea) on tomato and bean plants by using local isolates of Trichoderma harzianum. Dirasat Agricultural Sciences. 2005; 32(2):145-156.

4. Harman GE. Overview of mechanisms and uses of Trichoderma spp. Phytopathology. 2006; 96(2):190-194.

5. Harman GE, Howell CR, Viterbo A, Chet I, Lorito M. Trichoderma species opportunistic, a virulent plant symbionts. Nature Reviews Microbiology. 2004; 2:43-56. 
6. Shoresh M, Harman GE, Mastouri F. Induced systemic resistance and plant responses to fungal biocontrol agents. Annual Review of Phytopathology. 2010; 48:21-43.

7. Cummings NJ, Ambrose A, Braithwaite M, Bissett J, Roslan HA, Abdullah J, Stewart A, Agbayani FV, Steyaert J, Hill RA. Diversity of root-endophytic Trichoderma from Malaysian Borneo. Mycological Progress. 2016; 15:50 DOI 10.1007/s11557-016-1192$\mathrm{x}$.

8. Campanile G, Ruscelli A, Luisi N. Antagonistic activity of endophytic fungi towards Diplodia corticola assessed by in vitro and in planta tests. European Journal of Plant Patholology. 2007; 117:237-246.

9. Domsch KH, Gams WH, Anderson TH. 1980. Compendium of soil fungi, Vol-1, Academic Press (London).

10. Ellis MB. 1971. Dematiaceous hypomycetes. CAB International. Wallingford. UK.

11. Watanabe T. Pictorial atlas of soil and seed fungi: morphologies of cultured fungi and key to species (2nd ed.). 2002. CRC Press LLC, NW Corporate Blvd, Boca Raton, Florida.

12. Dennis C, Wesbter J. Antagonistic properties of species-group of Trichoderma. III. Hyphal Interactions. Transactions of the British Mycological Society. 1971; 57:363-369.

13. Ziedan El-Sayed HE, Farrag Eman SH, Sahab AF. Effect of Trichoderma harzianum against Thielaviopsis paradoxa and their pathological potential on date palm seedlings. Journal of Agricultural Technology. 2015; 11(4):913-923.

14. Naik BS, Shashikala J, Krishnamurthy YL. Study on the diversity of endophytic communities from rice (Oryza sativa L.) and their antagonistic activities in vitro. Microbiological Research. 2009; 164:290-296.

15. Terhonen E, Kerio S, Sun H, Asiegbu FO. Endophytic fungi of Norway spruce roots in boreal pristine mire, drained peatland and mineral soil and their inhibitory effect on Heterobasidion parviporum in vitro. Fungal ecology. 2014; 9:17-26.

16. Martínez-Álvarez P, Alves-Santos FM, Diez JJ. In vitro and in vivo interactions between Trichoderma viride and Fusarium circinatum. Silva Fennica. 2012; 46(3):303-316.

17. Mukherjee PK, Raghu K. Effect of temperature on antagonistic and biocontrol potential of Trichoderma sp. on Sclerotium rolfsii. Micropathologia. 1997; 139:151-155.

18. El-Katatny MH, El-Katatny MS, Fadl-Allah EM, Emam AS. Antagonistic effect of two isolates of Trichoderma harzianum against postharvest pathogens of tomato (Lycopersicon esculentum). Archives of Phytopathology and Plant Protection. 2011; 44(7):637654
19. Fajola AO, Alasoadura SO. Antagonistic effects of Trichoderma harzianum on Pythium aphanidermatum causing the Damping off disease of tobacco in Nigeria. Mycopathologia. 1975; 57(1):47-52.

20. Rajathilagam R, Kannabiran B. Antagonistic effects of Trichoderma viride against anthracnose fungus Colletotrichum capsici. Indian Phytopathology. 2001; 54(1):135-136.

21. Ganie SA, Ghani MY, Nissar Q, Shabir-u-Rehman. Bioefficacy of plant extracts and biocontrol agents against Alternaria solani. African Journal of Microbiology Research. 2013; 7(34):4397-4402.

22. Naglot A, Goswami S, Rahman I, Shrimali DD, Yadav KK, Gupta VK, Rabha AJ, Gogoi HK, Veer V. Antagonistic potential of native Trichoderma viride strain against potent tea fungal pathogens in North East India. The Plant Pathology Journal. 2015; 31(3):278-289.

23. Sundaramoorthy S, Balabaskar P. Biocontrol efficacy of Trichoderma spp. against wilt of tomato caused by Fusarium oxysporum f. sp. lycopersici. Journal of Applied Biology and Biotechnology. 2013; 1 (03): 36-40.

24. Benitez T, Rincn AM, Limn MC, Codn AC. Biocontrol mechanisms of Trichoderma strains. International Microbiology. 2004; 7:249260.

25. Elad Y. Biological control of foliar pathogens by means of Trichodema harzianum and potential modes of action. Crop Protection. 2000; 19:709-714.

26. Zeilinger S, Galhaup C, Payer K, Woo SL, Mach R.L, Fekete C, Lorito, M, Kubicek CP. Chitinase gene expression during mycoparasitic interaction of Trichoderma harzianum with its host. Fungal Genetics and Biology. 1999; 26:131-140.

\section{How to cite this article:}

Talapatra K, Das AR, Saha AK, Das P. In vitro antagonistic activity of a root endophytic fungus towards plant pathogenic fungi. J App Biol Biotech. 2017; 5 (02): 068-071. 